\title{
Effect of Pulse Beetle, Callosobruchus Chinensis L on Oviposition and Damage in Some Important Genotypes of Pulse Crops in Bangladesh
}

\author{
Salim Ahmed ${ }^{1}$, Md. Azizul Haque ${ }^{2}$ and Hyat Mahmud*3 \\ ${ }^{1}$ Upazila Agriculture Officer, kumarkhali, Kushtia \\ ${ }^{2}$ Department of Entomology, Bangladesh Agricultural University, Mymensingh, Bangladesh \\ ${ }^{3}$ Additional Deputy Director (Crop), Department of Agricultural Extension, Kushtia, Bangladesh
}

Received: January 21, 2018; Published: February 07, 2018

*Corresponding author: Hyat Mahmud, Additional Deputy Director (Crop), Department of Agricultural Extension, Kushtia, Bangladesh

\begin{abstract}
Reaction of pulse beetle, Callosobruchus chinensis L. to 20 genotypes of pulses belonging to lentil (Lens culinaris Medik.), mungbean (Vigna radiata (L) R. Wilczek), chickpea (Cicer arietinum L.) and blackgram (Vigna mungo (L). Hepper) was evaluated in no choice test in the laboratory of the Department of Entomology, Bangladesh Agricultural University, Mymensingh for observing the number of eggs deposition on seeds and percentage of damage of seed. Highest (73.1) number of eggs was laid on chickpea, while the lowest (19.5) was in blackgram. The results revealed that all the genotypes of chickpea were found to have highly susceptible to pulse beetle and blackgram genotypes were least susceptible. The susceptibility of lentil and mungbean were observed intermediate. Maximum (24.4\%) of seed damage was observed on chickpea and the minimum (6.9\%) was recorded in blackgram. Except blackgram, all the tested genotypes of chickpea, lentil and mungbean differed significantly for their susceptibility to the pulse beetle. The genotypes ML-22 of lentil, MC-21 of mungbean, Hyprosola of chickpea and MAK-1-79 of blackgram were marked least susceptible in comparison with the tested genotypes of respective pulse species. Seed surface smoothness, seed coat thickness and chemical stimuli influenced on the oviposition and damage of pulses by the pulse beetle.
\end{abstract}

Keywords: Cicer arietinum L; Callosobruchus chinensis L; Damage; Lens culinaris Medik; Oviposition; Seed; Susceptible; Vigna radiata L.R. Wilczek; Vigna mungo L Hepper

\section{Introduction}

Pulses play a vital role in the diet of common people of Asian countries including Bangladesh. Because pulses are the rich source of protein, several amino acids, minerals and certain vitamins, and are available to the poor people at a reasonable price. Pulses are also known as "Poor man's meat" Sharma [1]. An adult person can fulfill his daily protein requirement by consuming only $56 \mathrm{~g}$ of pulses, Susmita [2]. Unfortunately, the average per head pulse consumption in Bangladesh is only $14 \mathrm{~g}$, Nahar [3]. As a result, the people of Bangladesh suffer from malnutrition. Insufficient protein intake adversely affects health, survival intelligence, learning capacity and working efficiency. The production of pulses in Bangladesh is very low as 1037000 tons compared to total national requirements of 2628000 tons per year, AIS [4]. Bangladesh imports pulses from abroad every year at the cost of its hard earned foreign currency. Government of Bangladesh emphasizes to produce more pulses but the production has not yet been increased up to the requirement. There are many factors responsible for low productivity. One of the major constraints in production of pulses is the insect pests which inflict severe losses both in the field and storage. All pulse growers store the required quantity of pulse seeds in their house for growing next year.

Unfortunately, in storage, pulses suffer enormous losses due to pest attack. Among the insect pests, $C$. chinensis is the most serious pest of pulses and is known to be prolific and rapid in breeding, and can quickly cause a serious quantitative reduction as well as diminish nutritive value of stored grains. This insect is cosmopolitan in distribution but is more widely spread throughout the tropical and sub-tropical regions, Mensah [5]. The adult pulse beetles do not eat the seeds but they mate and oviposit on them. The newly hatched larva bores into the seed and starts feeding on its contents till the whole endosperm are eaten up. However C. chinensis is not only considered to be the most destructive insect but also causing severe damage to the extent of $93.33 \%$ in different pulse crops, Parsai [6]. Although there is no actual loss estimate in farmer's 
storage system, as high as 98.04, 73.20, 54.37 and $64.33 \%$ grains of mungbean, black gram, lentil and chickpea, respectively were reported to be infested by pulse beetle in Bangladesh, Anonymous [7]. In Bangladesh usually synthetic chemical insecticides and fumigants are used to protect the pulses from the infestation of pulse beetle in storage. But the use of chemical insecticides causes several problems like resistance and toxic residues in food.

However, the use of chemical pesticides not only involves potential health hazards, residues, pollution, contamination, but also beyond the financial capability of the farmers, Khaire [8]. It is an urgent need to find out a safe and sound alternative to chemical insecticides to protect the stored products in storage. During the last two decades voluminous research works are carried out on botanicals with little success. Recently researchers have paid much attention to develop resistant variety to the pest. The works on the varietal susceptibility of gram and other pulses have been reported from India, Bangladesh, Pakistan, Occidental and Oriental Countries, but information of the different varieties of lentil, mungbean, chickpea and black gram is not so available in Bangladesh. Bangladesh Institute of Nuclear Agriculture (BINA) has selected some genotypes of chickpea, lentil, mungbean and black gram with a view to develop new variety. Before releasing it is important to test these genotypes for their resistance to pulse beetle. The present study has been undertaken to evaluate the degree of susceptibility of the selected genotypes of these pulses to $C$. chinensis.

\section{Materials and Methods}

Experiment on the reaction of the pulse beetle, C. chinensis L. to 20 genotypes of four pulse species was conducted in the laboratory of the Department of Entomology, Bangladesh Agricultural University, Mymensingh, Bangladesh during June-September, 1999. Reaction of $C$. chinensis was studied in no-choice test for observing the oviposition and damage to pulse seeds. The experiment was carried out at room temperature from 28 to $33{ }^{\circ} \mathrm{C}$ and relative humidity of 68 to $75 \%$.

\section{Collection of Test Materials}

Four species of pulses, munghean (Vigna radiata (L.) R. Wilczek), chickpea (Cicer arietinum L.), lentil (Lens culinaris Medik.) and blackgram (Vigna mungo (L.) Hepper) with five genotypes of each species were used in this study. The seeds of all the tested genotypes were collected from the Department of Genetics, Bangladesh Institute of Nuclear Agriculture, Mymensingh, Bangladesh.'

Table 1: Number of eggs laid and percent damage by C. chinensis on seeds of different pulses.

\begin{tabular}{|c|c|c|c|c|c|c|c|c|}
\hline \multirow{2}{*}{ Pulses } & \multicolumn{3}{|c|}{ Number of eggs } & \multirow{2}{*}{ Mean \pm SE } & \multicolumn{3}{|c|}{ Percent seed damage } & \multirow{2}{*}{$\begin{array}{c}\text { Mean } \\
\text { damage }(\%)\end{array}$} \\
\hline & $\mathrm{R}_{1}$ & $\mathbf{R}_{2}$ & $\mathbf{R}_{3}$ & & $\mathrm{R}_{1}$ & $\mathbf{R}_{2}$ & $\mathbf{R}_{3}$ & \\
\hline Lentil & 57.2 & 58.2 & 52.6 & $56.0 \pm 1.7 \mathrm{~b}$ & 12.1 & 12.5 & 12.2 & $12.3 \mathrm{~b}$ \\
\hline Mungbean & 61.0 & 62.6 & 54.8 & $59.5 \pm 2.4 \mathrm{~b}$ & 13.7 & 11.5 & 12.3 & $12.5 \mathrm{~b}$ \\
\hline Chickpea & 74.4 & 73.6 & 71.4 & $73.1 \pm 0.9 \mathrm{a}$ & 24.5 & 24.1 & 24.5 & $24.4 \mathrm{a}$ \\
\hline Blackgram & 19.6 & 19.4 & 19.4 & $19.5 \pm 0.07 \mathrm{c}$ & 5.9 & 7.9 & 6.8 & $6.9 \mathrm{c}$ \\
\hline
\end{tabular}

Note: *Means in a column followed by the same letter are not significantly different.

\section{Stock Culture of Pulse Beetle}

Several numbers of pulse beetle collected from the Department of Entomology, Bangladesh Agricultural University, Mymensingh were allowed to oviposit in a large glass jar $(12 \mathrm{~cm} \times 18 \mathrm{~cm})$ having $100 \mathrm{~g}$ seeds of gram. After oviposition, the adult pulse beetles were removed and seeds along with eggs were left for emerging as adult in the jar. Newly emerged adults were again allowed to oviposit on new seeds and the procedure was continued to maintain a steady stock culture of the test insect.

\section{Oviposition Test}

Seeds of ninety grams for each genotype of pulses were divided into three equal parts (each $30 \mathrm{~g}$ ) and kept in three separate Petri dishes $(8.5 \mathrm{~cm} \times 1.5 \mathrm{~cm})$. Each dish was considered as a replicate. Thus the total number of Petri dish was 60 . Four pairs of newly emerged adult pulse beetles were released in each Petri dish and were allowed to lay eggs. Five gram seed randomly from each replicate was used. After five days, the insects were removed and the number of eggs laid on seeds was counted with the help of magnifying glass. Then the Petri dishes were covered with lid and kept on the table for damage assessment.

\section{Damage Assessment}

The Petri dishes containing pulse seeds of four species with five genotypes were used to determine the damage in the oviposition test. After 30 days of ovipsition, the holes made by the insect on the surface of seeds were carefully examined. The damaged seeds were counted for each replicate and genotype. The percentage of damage was calculated by using the following formula.

$$
\text { Percent Damage }=\frac{\text { Number of Damaged Seeds }}{\text { Total number of seeds }} \times 100
$$

\section{Results}

\section{Effect on Pulse Species}

The number of eggs deposited by the females of $C$. chinensis on different species of pulses was presented in (Table 1). Significant difference was found among different species of pulses with number of eggs $(\mathrm{P}<0.01)$. Highest number of eggs $(73.1)$ was laid on chickpea, while the lowest (19.5) was in blackgram. The number of eggs laid on chickpea was four times higher than blackgram. In case of percent damage of seed, significant difference was observed among different species of pulses $(\mathrm{P}<0.01)$. Minimum $(6.9 \%)$ of seed damage was achieved in blackgram followed by lentil, mungbean and chickpea. 


\section{Effect on Lentil}

The number of eggs laid on different genotypes of lentil was shown in (Table 2). The number of eggs showed differed significantly among the genotypes $(\mathrm{P}<0.01)$. Maximum number of eggs (96.33) was laid on BARI Masur-4, while the minimum (44.33) on ML-22 which was statistically identical with ML-432, ML-9 and ML-478. The seed damage showed differed significantly among the genotypes $(\mathrm{P}<0.01)$. Highest $(16.6 \%)$ seed damage was noted with BARI Masur-4. The lowest (10.1\%) seed damage was observed in ML-432.

Table 2: Number of eggs laid and percent damage by C. chinensis on seeds of different genotypes of lentil.

\begin{tabular}{|c|c|c|c|c|c|c|c|c|}
\hline \multirow{2}{*}{ Genotypes } & \multicolumn{3}{|c|}{ Number of eggs } & \multirow{2}{*}{ Mean $\pm S E$} & \multicolumn{3}{|c|}{ Percent seed damage } & \multirow{2}{*}{$\begin{array}{c}\text { Mean } \\
\text { damage (\%) }\end{array}$} \\
\hline & $\mathrm{R}_{1}$ & $\mathbf{R}_{2}$ & $\mathbf{R}_{3}$ & & $\mathbf{R}_{1}$ & $\mathbf{R}_{2}$ & $\mathbf{R}_{3}$ & \\
\hline ML- 432 & 42 & 49 & 48 & $46.33 \pm 2.18 b$ & 9.9 & 9.0 & 11.4 & $10.1 \mathrm{c}$ \\
\hline BARI Masur-4 & 107 & 103 & 79 & $96.33 \pm 8.74 \mathrm{a}$ & 16.2 & 17.8 & 16.2 & $16.6 \mathrm{a}$ \\
\hline ML-22 & 45 & 47 & 41 & $44.33 \pm 1.76 \mathrm{~b}$ & 10.7 & 12.2 & 10.3 & $11.1 \mathrm{bc}$ \\
\hline ML-9 & 44 & 47 & 52 & $47.66 \pm 2.33 \mathrm{~b}$ & 10.1 & 11.9 & 10.2 & $10.7 \mathrm{c}$ \\
\hline ML-478 & 48 & 45 & 43 & $45.33 \pm 1.45 \mathrm{~b}$ & 13.4 & 11.7 & 13.1 & $12.7 \mathrm{~b}$ \\
\hline
\end{tabular}

Note: *Means in a column followed by the same letter are not significantly different.

\section{Effect on Mungbean}

The C. chinensis showed differential response to different genotypes of mungbean. There were significant differences among different genotypes of mungbean $(\mathrm{P}<0.05)$ with number of eggs laid by the beetles (Table 3 ). The maximum number of eggs (68) was recorded on MC-26 which was statistically identical with
Binamoog-5 and MC-36. The lowest number of eggs (51.3) was deposited on MC-21, which was statistically similar to Binamoog-2. C. chinensis also caused damage to mungbean seeds at different rates. Highest seed damage (16.4\%) was found on MC-26 which was significantly similar to Binamoog-5. The lowest $(8.2 \%)$ seed damage was observed in MC-21, which was significantly similar to MC-36.

Table 3: Number of eggs laid and percent damage of by C. chinensis on seeds of different genotypes of mungbean.

\begin{tabular}{|c|c|c|c|c|c|c|c|c|}
\hline \multirow{2}{*}{ Genotypes } & \multicolumn{3}{|c|}{ Number of eggs } & \multirow{2}{*}{ Mean \pm SE } & \multicolumn{3}{|c|}{ Percent seed damage } & \multirow{2}{*}{$\begin{array}{c}\text { Mean } \\
\text { damage (\%) }\end{array}$} \\
\hline & $\mathrm{R}_{1}$ & $\mathbf{R}_{2}$ & $\mathbf{R}_{3}$ & & $\mathrm{R}_{1}$ & $\mathbf{R}_{2}$ & $\mathbf{R}_{3}$ & \\
\hline MC-26 & 69 & 71 & 64 & $68.0 \pm 2.1 \mathrm{a}$ & 17.6 & 15.2 & 16.3 & $16.4 \mathrm{a}$ \\
\hline Binamoog-2 & 53 & 57 & 51 & $53.7 \pm 1.8 \mathrm{bc}$ & 14.7 & 10.5 & 12.3 & $12.5 \mathrm{bc}$ \\
\hline MC - 36 & 65 & 67 & 51 & $61.0 \pm 5.0 \mathrm{ab}$ & 11.6 & 11.2 & 8.4 & $10.4 \mathrm{~cd}$ \\
\hline Binamoog-5 & 67 & 64 & 59 & $63.3 \pm 2.3 \mathrm{a}$ & 15.1 & 14.3 & 16.1 & $15.1 \mathrm{ab}$ \\
\hline MC-2I & 51 & 54 & 49 & $51.3 \pm 1.5 \mathrm{c}$ & 9.7 & 6.5 & 8.3 & $8.2 \mathrm{~d}$ \\
\hline
\end{tabular}

Note: *Means in a column followed by the same letter (s) are not significantly different.

\section{Effect on Chickpea}

It was observed that $C$. chinensis laid eggs on all tested genotypes of chickpea but their number varied significantly as shown in (Table 4). Significantly lowest (55.7) number of eggs were recorded on Hyprosola. The highest number of eggs (84.3) was laid on BARI
Sola-3, which was statistically identical with P-34, L-84 and BARI Sola-5. The percentage of seed damage differed significantly among the genotypes $(\mathrm{P}<0.01)$. Maximum $35.8 \%$ of seed damage was found to observe in BARI Sola-3. The lowest $14.6 \%$ in seed damage was obtained with Hyprosola.

Table 4: Number of eggs laid and percent damage by C. chinensis on seeds of different genotypes of chickpea.

\begin{tabular}{|c|c|c|c|c|c|c|c|c|}
\hline \multirow{2}{*}{ Genotypes } & \multicolumn{3}{|c|}{ Number of eggs } & \multirow{2}{*}{ Mean \pm SE } & \multicolumn{3}{|c|}{ Percent seed damage } & \multirow{2}{*}{$\begin{array}{c}\text { Mean damage } \\
(\%)\end{array}$} \\
\hline & $\mathbf{R}_{1}$ & $\mathbf{R}_{2}$ & $\mathbf{R}_{3}$ & & $\mathbf{R}_{1}$ & $\mathbf{R}_{2}$ & $\mathbf{R}_{3}$ & \\
\hline P-34 & 84 & 71 & 68 & $74.3 \pm 4.91 \mathrm{a}$ & 25 & 20 & 21.4 & $22.1 \mathrm{bc}$ \\
\hline Hyprosola & 51 & 60 & 56 & $55.7 \pm 2.6 \mathrm{~b}$ & 14.6 & 10.5 & 18.6 & $14.6 \mathrm{~d}$ \\
\hline BARI Sola - 3 & 89 & 78 & 86 & $84.3 \pm 3.28 \mathrm{a}$ & 27 & 46.1 & 34.4 & $35.8 \mathrm{a}$ \\
\hline L-84 & 81 & 73 & 76 & $76.7 \pm 2.33 \mathrm{a}$ & 17.1 & 16.7 & 21.4 & $18.4 \mathrm{~cd}$ \\
\hline BARI Sola-5 & 67 & 86 & 71 & $74.7 \pm 5.78 \mathrm{a}$ & 28.6 & 27.3 & 27.6 & $27.8 \mathrm{~b}$ \\
\hline
\end{tabular}

Note: *Means in a column followed by the same letter are not significantly different.

\section{Effect on Blackgram}

C. chinensis oviposited eggs on all the tested five genotypes in the blackgram seeds. Egg laying did not differ significantly among the genotypes. Maximum number (22.0) of eggs was laid on M-2554, while the lowest (17.3) was recorded in MAK-1-79. The highest seed damage (8.2\%) was observed in genotypes M-25-58 and the lowest (5.3\%) was found in Binamash-1 (Table 5). 
Table 5: Number of eggs laid and percent damage by C. chinensis on seeds of different genotypes of blackgram.

\begin{tabular}{|c|c|c|c|c|c|c|c|c|}
\hline & \multicolumn{3}{|c|}{ Number of eggs } & \multirow{2}{*}{ Mean \pm SE } & \multicolumn{3}{|c|}{ Percent seed damage } & \multicolumn{2}{c|}{ Mean } \\
\cline { 2 - 3 } & $\mathbf{R}_{\mathbf{1}}$ & $\mathbf{R}_{\mathbf{2}}$ & $\mathbf{R}_{\mathbf{3}}$ & & $\mathbf{R}_{\mathbf{1}}$ & $\mathbf{R}_{\mathbf{2}}$ & $\mathbf{R}_{\mathbf{3}}$ & damage (\%) \\
\hline Binamash-1 & 17 & 21 & 19 & $19.0 \pm 1.2$ & 5.7 & 6.1 & 4.3 & 5.3 \\
\hline MAK-1-79 & 19 & 18 & 15 & $17.3 \pm 1.2$ & 5 & 9.2 & 7.3 & 7.2 \\
\hline M-25-54 & 21 & 19 & 26 & $22.0 \pm 2.1$ & 5.2 & 8.1 & 7.1 & 6.8 \\
\hline M-25-58 & 19 & 20 & 16 & $18.13 \pm 1.2$ & 8.6 & 6.8 & 9.3 & 8.2 \\
\hline MAK-1 & 22 & 19 & 21 & $20.7 \pm 0.9$ & 5.4 & 7.6 & 6.1 & 6.4 \\
\hline
\end{tabular}

\section{Discussion}

Highest eggs deposition occurred on chickpea and the lowest eggs deposition was found in blackgram among the pulse species. The egg deposition on mungbean and lentil were intermediate. The results are in agreement with the findings of Singh, [9] who reported that $C$. chinensis preferred oviposition to chickpea followed by mungbean, lentil, blackgram and bean in order of decreasing suitability. Bhaduria and Jakhmola [10] reported that the ovipositional preference and survival of the pulse beetles on black gram which were less preferred for oviposition. The variation of egg deposition on different pulse species associated with the morphological characteristics of the seeds. The seeds of chickpea were large in size having larger surface area which favoured larger egg deposition. Chakraborty and Mondal [11] reprted that pulse beetle laid maximum number of eggs in larger surface area of seed in kidney bean. This was in conformity with the observation of Teotia and Singh [12] who reported that the fecundity of $C$. chinensis depended upon the size and quality of seeds with seed coat. Although the seeds of lentil and mungbean are small in size than blackgram but the egg deposition was higher on lentil and mungbean seeds. The smooth seed surface and well filled seeds of lentil and mungbean encouraged the beetle for higher egg deposition which was supported by Nwanze and Horber [13].

They reported that $C$. chinensis laid higher number of eggs on lentil and mungbean genotypes with small seed size and smooth seed surface than those pulse seeds with rough seed surface. The present findings were supported with the report of Girish et al. [14] where the ovipositional and developmental period have been guided by smoothness of seed coat of the grain. Maximum seed damage was observed in chickpea and minimum in blackgram. The second highest damage was observed in mungbean followed by lentil. The number of larvae of $C$. chinensis feed inside the seeds that are responsible for higher damage. These findings were supported by Sharma et al. [15], Aslam [16], and Khare and Johari [17]. Khare and Johari [17] reported that severe infestation of chickpea lost their germination and led to $100 \%$ damage. Besides this, chickpea was found more suitable and blackgram was less suitable for feeding by the pulse beetle larvae. Lentil seeds were the smallest with damage of $12.3 \%$, while blackgram seeds were the medium sized with $6.9 \%$. This result indicated that the size of the pulse seed did not show any effect on the damage of the seed. So the thickness of seed coat had greater impact on the damage of the seed which can be correlated with work of Podoler and Applebaum [18,19] and observed that thicker seed coat reduced damage to various pulse seeds. However, it is evident from the literature that higher seed weight and thick seed coat prolonged developmental period, Chakraborty et al. [20].

The pulse beetle, $C$. chinensis L. laid eggs on the seed coat and the larvae fed inside the seed. The pulse seeds of all the genotypes of chickpea, lentil, mungbean and blackgram were exposed to the pulse beetle and found the deposition of eggs. The rate of oviposition differed significantly among the genotypes of respective pulse species. The lower number of eggs was deposited on the genotype ML-22 in lentil, MC-21 in mungbean, Hyprosola in chickpea and MAK.-1-79 in blackgram. The seeds of the five genotypes in a species were not found to have well differentiated by their morphological characteristics such as size, shape, colour and seed surface. Egg deposition among various genotypes in a given species varied due to some ovipositional deterrent presence on the seed coat which was supported by Yamamoto [21]. Chakraborty and Mondal [11] investigated that relative preference of $C$. chinensis to different pulses varied widely depending upon their physical and chemical characteristics. Ovipositional preference was dependent on the seed color, seed texture, seed weight, thickness of seed coat, seed moisture and various chemical parameters. These findings were in accordance with the observation of Schoonhoven [22] and found the variations in influence on the oviposition of the pulse beetle attributed to the odour emanating from the seed.

Seed damage differed significantly among the genotypes of the pulses species. Among the genotypes of respective pulse species, the lower seed damage was found in ML-432 in lentil, MC-26 in mungbean, Hyprosola in chickpea and Binamash-I in blackgram. The present study on the damage level of pulse beetle to pulse seed showed that none of the twenty tested genotypes under the four species was free from the damage by pulse beetle. Singh and Sing [23] reported that none of the tested promising varieties of lentil was found immune to infestation of $C$. chinensis but there were appreciable differences in their susceptibility to the pest. This work is supported by Weigand and Tahhano [24] who reported that screening of infestation (0-79\%) did not reveal any acceptable degree of resistance but some wild accessions were resistant.

\section{Conclusion}

From the present findings, the pulse beetle, Collosobruchus chinensis $\mathrm{L}$ resulted in higher susceptibility in chick pea and marked the lowest susceptibility in blackgram. C. chinensis L. also showed maximum number of egg deposition and highest damage in larger surface area of chickpea seed. Number of laid eggs also varied 
according to the surface area of seed, and chemical composition of seed also has significant contributions in influencing the egg deposition and damage of seed.

\section{Acknowledgment}

It feels me a great pleasure to express my heartfelt gratitude my honorable research supervisor, Professor Dr. Md. Azizul Haque, Department of Entomology, Bangladesh Agricultural University, Mymensingh.

\section{References}

1. Sharma SS (1984) Review of literatures of the losses caused by Callosobruchus species (Bruchidae: Coleoptera) during storage of pulses. Bulletin of Grain Technology 22(1): 62-68.

2. Susmita Das (2016) Pulses Production in Bangladesh: Status and Drivers for Enhancement. Bangladesh Agricultural Research Council, Dhaka.

3. Nahar Q Choudhury S, Faruque MO, Sultana SSS, Siddiquee MA (2013) Desirable Dietary Pattern for Bangladesh. Bangladesh Institute of Research and Rehabilitation in Diabetes, Endocrine and Metabolic Disorders (BIRDEM), National Food Policy Capacity Strengthening Programme, Ministry of Food, Bangladesh.

4. AIS (2017) Pulse Production in 2016-17 in Bangladesh, Agriculture information Service, Department of Agricultural Extension, Dhaka, Bangladesh.

5. Mensah GWK (1986) Infestation potentials of bruchids on cowpea cultivars stored under subtropical conditions. Fac Agril Univ Swaziland 7(6): 781-784.

6. Parsai SK, Rawat RR, Choudhary RK (1989) Ovipositional behaviour and preference of Callosobruchus phaseoli (Gyllehal.): its extent of damage in storage seeds of different varieties of fieldbean. Bulletin of Grain Technology 27(2): 103-106.

7. Anonymous (1984) Pulse beetle incidence in stored pulses and control measures. Annual Report, Legumes Post harvest Technology, Bangladesh. Bangladesh Agril Res Inst, Joydebpur, Gazipur, Bangladesh, pp. 6-13.

8. Khaire VM, Kachare BV, Mote UN (1993) Effects of vegetable oils on mortality of pulse beetles on pigeon pea seeds. Mahatama Phule Agricultural University, India. Journal of Seed Research 21(2): 71-81.

9. Singh Y (1976) Studies on relative resistance of important pulses to Callosobruchus maculatus (Fabricius) and Callosobruchus chinensis (Linnaeus). Entomologists Newsleter 6 (2): 18-19.

10. Bhaduria NS, Jakhmola SS (2006) Effect of intensity of infestation caused by pulse beetle on extent of losses and seed germination in different pulses. Indian Journal of Entomolgy 68: 92-94.

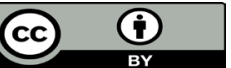

This work is licensed under Creative Commons Attribution 4.0 License

Submission Link: http://biomedres.us/submit-manuscript.php
11. Chakraborty S, Mondal P (2016) Physico-chemical parameters of pulses affecting the bruchid (callosobruchus Chinensis linn) Infestation. Asian Journal of Science and Technology 7(3): 2554-2560.

12. Teotia TPS, Singh VS (1968) The effect of host species on the oviposition, fecundity and development of Callosobruchus chinensis L (Bruchidae: Coleoptera). Rev Appi Ent 56(3): 171

13. Nwanze KF, Horber E (1976) Seed coat of cowpeas affect oviposition and larval development of Callosobruchus maculatus Fab. Environ Ent 4: 8-14.

14. Girish GK, Singh K, Murthy K (1974) Studies on oviposition and development of Callosobruchus maculatus (Fab) in various stored pulses. Bull Grain Tech 12: 113-116.

15. Sharma Rupesh, Devi R, Soni A, Sharma U, Yadav S, et al. (2016) Growth and developmental responses of Callosobruchus maculatus (F) on various pulses. Legume Research 39(5): 840-843.

16. Aslam M (2004) Pest Status of Stored Chickpea Beetle, Callosobruchus chinensis Linnaeus on Chickpea. Journal of Entomology 1(1): 28-33.

17. Khare BP, Johari RK (1984) Influence of phenotypic characters of chickpea (Cicer arietinum L) cultivation their susceptibility to Callosobruchus chinensis (L). Legume Research 7: 54-56.

18. Podoler H, Applebaum SW (1968) Physiological aspects of hosts specificity in the Bruchidae. Varietal differences in the resistance of Vicia faba L. to Callosobruchus chinensis L. J stored Prod Res 4(1): 9-11.

19. Singal SK (1987) Preliminary biological studies of pulse beetle, Callosobruchus chinensis L on corticated and decorticated faba beans, Vicia faba L FABIS Newsletter. Faba Bean Inf Serv, ICARDA, 17: 33-35.

20. Chakraborty SN, Chaudhuri N, Senapati SK (2004) Correlation between seed parameters and relative susceptibility of mung bean genotypes to Callosobruchus chinensis during storage. Ann Pl Protect Sci 12: 48-50.

21. Yamamoto I (1990) Chemical ecology of bruchids. In Bruchids and Legumes: Economics, Ecology and coevolution. In: Fujii K. Gatehouse AMR, Johnson CD, Mitehel R, Yoshida T (Eds.) Kluwer Academic Publishers, London, pp. 53-62.

22. Schoonhoven LM (1972) Secondary plant substances and insects. In Structural and Functional Aspects of Phytochemistry and edited by Runeckles VC, Tso TC. 5: 197-224

23. Singh H, Singh L (1973) Screening of some lentil varieties against pulse beetle, Callosobruchus chinensis (Bruchidae:Coleoptera). Bull Grain Technol 11(2): 121-123.

24. Weigand S, Tahhano O (1990) Chickpea insects pests in the Mediterranean zones and new approaches to their management. Chickpea in the nineties: Proceedings of the 2nd International Workshop on Chickpea Improvement. Patancheru India, ICRISAT, pp. 169-175.

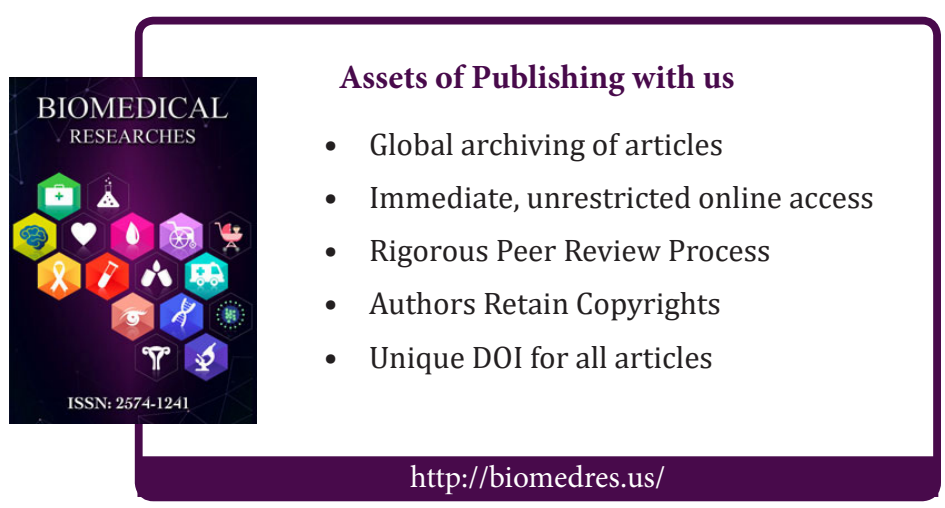

